\title{
Excepcionalismo y performances marianistas en Gabriela Mistral
}

\section{Exceptionalism and marianists performances in Gabriela Mistral}

\author{
Antonieta Vera Gajardo \\ Investigadora CISOC (Centro de Investigaciones Socioculturales), Universidad \\ Alberto Hurtado. Santiago, Chile. \\ mverag@uahurtado.cl
}

\section{Resumen}

El presente trabajo propone la noción "performances marianistas" como clave de lectura de algunas de las auto-representaciones que Gabriela Mistral habría utilizado en un contexto sociopolítico específico, en el cual el "excepcionalismo" se presenta como estrategia conducente a la promesa de igualdad. Este análisis nos llevará a pensar en las construcciones de género y "raza" de las cuales dependen los sistemas de valores que sostuvieron "la femineidad legítima" en la época en la que Mistral vivió.

El texto tiene tres partes: la primera enunciará algunos debates y tomará posición con respecto al relato del marianismo latinoamericano. La segunda, problematizará las estrategias paradójicas del "excepcionalismo". La última, propone una lectura de las figuras que sugiero leer bajo las claves del marianismo y del excepcionalismo: "la Maestra de América Latina" y "la Poeta Redentora".

Palabras clave: excepcionalismo, máscara, Gabriela Mistral, marianismo.

\section{Abstract}

This paper proposes the notion "Marianist performances" as a key to understand some of the self-representations Gabriela Mistral would have used in a specific socio-political context in which the "exceptionalism" is presented as a strategy leading to the promise of equality.This analysis leads us to reflect upon the constructions of gender and "race", dependent on the systems of value that supported "legitimate femininity" at the time in which Mistral lived.

The text is divided into three parts: the first enunciates a few debates and acquires a position in relation to the narrative of Latin American Marianism. The second, problematizes the paradoxical strategies of "exceptionalism". The last part, proposes a reading of the figures of "Master of Latin America" and "the Poet Redemptive" in the key of Marianism and exceptionalism.

Keywords: Exceptionalism, Mask, Gabriela Mistral, Marianism. 


\begin{abstract}
"Yo tengo arrimo en hombro que me vale, a ti los cuatro clavos ya te sueltan, y el encuentro se vuelve un recogerte la sangre como lengua que contesta, pasar mis manos por mi pecho enjuto, coger tus pies en peces que gotean ...

Acaba de llegar, Cristo, a mis brazos, peso divino, dolor que me entregan, ya que estoy sola en esta luz sesgada y lo que veo no hay otro que vea..."
\end{abstract}

Gabriela Mistral

Nocturno del descendimiento

\title{
El relato marianista
}

El marianismo latinoamericano es un fenómeno heterogéneo que incluye prácticas, ritos y discursos religiosos en disputa. En el presente texto, sin embargo, mi objetivo es problematizar el relato y la representación marianista tal como han sido tematizados por dos de los pensadores importantes sobre el tema: Octavio Paz y Sonia Montecino.

$\mathrm{Si}$ es posible afirmar que las reflexiones de Paz inspiran en gran medida el trabajo de Montecino, es necesario interrogar algunos de sus supuestos. Al respecto, me interesa particularmente "la relación de oposición complementaria" (Paz 1950) que el autor establece tanto entre la Virgen de Guadalupe y Cuauhtémoc, como entre la Virgen de Guadalupe y la Malinche. Así, si la pregunta por "el origen de la raza mestiza latinoamericana" nos lleva de una u otra manera al imaginario nacional del que fuera el primer imperio "penetrado" por los conquistadores, cabría subrayar aquellas narrativas en las que la resistencia y el orgullo comunitario se dicen en masculino (Cuauhtémoc) y la debilidad y la deserción en femenino (Malinche). Según el relato de Paz, el producto de toda esta vergüenza originaria sería "el hijo mestizo" ${ }^{1}$, sujeto masculino trágico y melancólico que, perdido en "el laberinto de su soledad", cuenta el relato nacional en primera persona.

En este imaginario del mestizaje, "el español conquistador", "la india violada" y "el indio derrotado" son los personajes de un relato a partir del cual los pueblos

1 A lo largo del texto, utilizaré las comillas para señalar el carácter construido de categorías raciales y estereotipos culturales. 
precolombinos son pensados como una unidad homogénea "penetrada" por "el europeo", quien encarnaría "la pureza blanca". Si estas representaciones bipartitas y género-racializadas del "mestizaje" participan del objetivo de "inventar una tradición” (Hobsbawn y Ranger 2002), cabría identificar algunas de las preguntas que ese imaginario evita: ¿Por qué el único sujeto deseante de este relato es "el hombre blanco"? ¿Qué pasa con el deseo de los/las colonizados/as o con el deseo colonial de las mujeres "blancas"? (Boidin 2008) ¿Qué ocurre con el deseo no-heterosexual en el relato nacional? ¿Por qué parece operar la idea tácita de un "paraíso precolombino" cuando lo que existía en lugar de esa unidad, eran varios pueblos en conflicto? Y finalmente: ¿cuáles son las incidencias, sobre la representación del cuerpo femenino, de un imaginario latinoamericano articulado por el relato de una derrota? (Franco 1989; Vera 2012).

Esta última pregunta nos conduce a la segunda pareja de representaciones en juego: la Malinche y la Virgen de Guadalupe. Figuras interdependientes y por lo mismo problemáticas, ya que reposan en un binarismo clave para la religión católica: Eva y María.

No es casual que Paz nombre a Malinche "la Eva mexicana", figura de cuyo repudio depende la afirmación nacional del "mestizo", quien buscará en la madre Guadalupe, un refugio para su vergüenza y orfandad. Sin posibilidad de reflexionar aquí sobre la vida de la mujer de carne y hueso que fue Malinalli -niña vendida por su madre y ofrecida en 1519 por los mayas de Potonchan a Hernán Cortés, junto a otras 19 mujeres (Díaz del Castillo, cit. en Baudot 23)-, cabe relevar su transformación en el ícono mudo y petrificado que más de cuatro siglos después de su muerte, continuaría simbolizando "la pasividad abierta de una violación consentida y secretamente deseada para engendrar la destrucción irremediable de un pueblo y de una cultura" (Baudot 19)2.

Bajo este imaginario, los cuerpos de las mujeres latinoamericanas se debatirían entre dos estrechas representaciones: la madre traidora, abierta, responsable del desgarrador sentimiento de orfandad y derrota del mestizo; y la madre cerrada, moralmente irreprochable e indisponible para otro hombre que no sea el hijo varón que cobija en su regazo. Así, el foco de nuestro problema apunta a los posibles efectos performativos ${ }^{3}$ de un relato atávico de humillación que imagina el cuerpo femenino como metáfora del territorio y de la vulnerabilidad/dignidad nacional. La desvirilización del "padre indígena" y del "hijo mestizo" serán atribuidas a ese cuerpo abierto.

La función política de la Malinche en el imaginario latinoamericano dependería, entonces, de esta relación de complementariedad tanto con Cuauhtémoc como

2 Todas las traducciones del inglés y del francés del presente texto son de la autora.

3 El uso que haré de la noción “performativo", se remite a la distinción del filósofo del lenguaje John Austin (enunciados constatativos y performativos -o "realizativos", es decir, que hacen lo que dicen-), retrabajada por Judith Butler en El género en disputa. Volveré sobre esta noción en el segundo apartado. 
con la Virgen de Guadalupe: gracias a esta "traidora perfecta” (Monsivais 2001), el héroe latinoamericano y la "buena madre de la nación" pueden permanecer estoicos, dignos, leales.

Avancemos ahora en el argumento de Montecino (2007) que sostiene que la Virgen de Guadalupe (la patrona del continente) y las Vírgenes mestizas en general, representarían "la síntesis cultural” y la posibilidad simbólica de la redención.

La caracterización de estas vírgenes como "mestizas", no sólo correspondería a la pigmentación de la piel, sino al proceso de mezcla del catolicismo español con las religiones paganas del continente. Así, el mito marianista resolvería -según Montecino- el conflicto planteado por el hecho de ser hijos de "una madre india violada" y de un "padre español", dándoles a los mestizos una identidad indudable en una "Madre común" (39). Las vírgenes mestizas jugarían entonces, un rol redentor en relación a la oposición legítimo/bastardo que emerge como expresión de la tensión colonial puro/impuro.

En su libro Reflexiones americanas, Marcos García de la Huerta planteará diversas críticas al texto de Montecino, de entre las cuales quisiera destacar dos. En primer lugar, lo que García de la Huerta nombra críticamente como "la valoración positiva de "la síntesis cultural mestiza":

¿es posible... postular la existencia de una identidad latinoamericana peculiar emanada de una síntesis cultural mestiza? ... ¿ ¿ómo podría 'emanar' de la enorme diversidad de culturas una sola identidad mixta? Si no hubo en rigor indios, sino sólo aztecas, incas, guaraníes, araucanos, mayas, etc., por qué tendría que haber un sincretismo y un mestizaje y no varios?... 'El mestizo' no existe, es otro concepto comodín como el de indio... (174-5, énfasis del autor).

Siguiendo a García de la Huerta, creo posible afirmar que tal como estaría planteada por Montecino, la noción "síntesis cultural mestiza" no problematizaría ni el carácter históricamente asimilacionista de la categoría racial "mestizo" ni la concepción biologicista de la que inevitablemente hace parte. En palabras de Zermeño-Padilla: "sin el factor Darwin, Gustave Le Bon, Herbert Spencer, la emergencia del mestizaje como idea reguladora de la comprensión de las naciones ibero-americanas no habría sido posible" (92). (Figuras 1 y 2)

Es, sin embargo, la segunda interrogante crítica de García de la Huerta sobre la cual quisiera detenerme: la valoración positiva de Montecino de un cierto "matriarcado" a la luz de la identificación entre la figura de "la Virgen mestiza" y "la madre soltera latinoamericana". Se trataría, para García de la Huerta, del riesgo de una "inversión simple del machismo" que además, se focalizaría en la figura del "niño huacho", dejando de lado a las "hijas sin padre"

4 Es importante considerar que a diferencia de la versión de 1991, en Madres y huachos del 2007 Montecino sí consagrará toda una nueva sección a la figura de "las huachas", aunque en el Chile contemporáneo (las "nanas", 


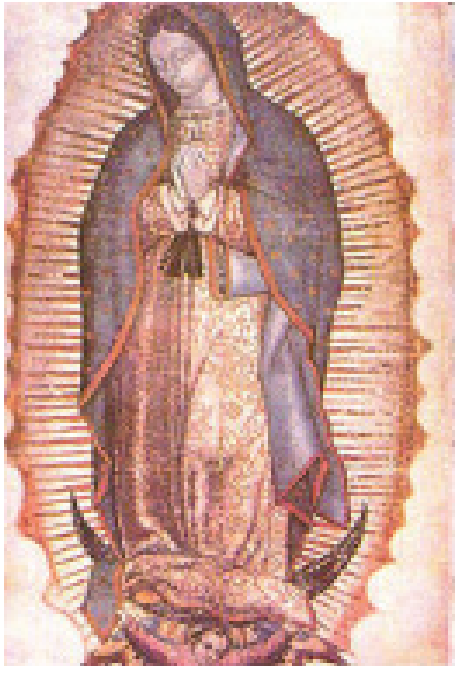

Figura 1. Virgen de Guadalupe. Grabado Siglo XVI. Nueva Basílica de Tepeyac, México.

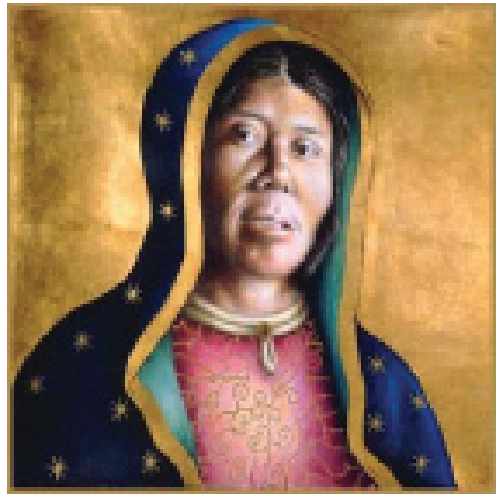

Figura 2. Retablo de la virgen indígena. Michael Walker, 1995.

Junto a la no-problematización de un imaginario del mestizaje cuyo locus de enunciación paradigmático es el del hijo varón, pienso que la reivindicación de Montecino de este empoderamiento de la figura marianista nos pone frente a algunas de las paradojas clásicas del feminismo, que giran en torno a la reapropiación del estigma como estrategia de autoafirmación. Al respecto, lo que Eleni Varikas (2007) ha denominado estrategia de inversión es una clave de lectura importante.

Se trataría, en efecto, de una estrategia que implica una revalorización positiva de aquello que ha sido subvalorado antes: lo "inferior" se vuelve "superior". Así, se recurre al argumento de una "naturaleza" o "cultura" compartida para movilizar la unidad de "la diferencia" anteriormente excluida. Históricamente, esta estrategia ha permitido crear identidades y movimientos políticos. Sin embargo, la inversión confirma el binarismo que es la clave de la dominación misma: no revierte la lógica de la dicotomía, sólo cambia sus valoraciones. Junto con ello, refuerza la idea de "unidad" a costa de la reproducción normativa, excluyente y/o esencialista de "la identidad".

La reivindicación matriarcal de la figura marianista parece corresponder al problema de la estrategia de inversión en la medida en que refuerza los binarismos a partir de los cuales se ha construido la idea del "origen mestizo". Efectivamente, el prestigio de Guadalupe en el relato hegemónico - por oposición a la traidora Ma- 
linche- depende de que su sexualidad permanezca o parezca clausurada y, en esa medida, respetable, incluso para el conquistador. De esta manera, y aún consignando sus resistencias paganas, resulta altamente problemático que sea bajo el nombre católico de "María" que intenten conjurarse las ansiedades nacionales en torno al cuerpo femenino racializado: las malinches, las "malas mujeres de la nación".

Así, sin desmentir completamente el potencial de la resignificación marianista, es posible sostener que en ella subsisten y se refuerzan binarismos y jerarquías implícitas, hasta hoy en conflicto (mestizo/indígena, católico/pagano, cuerpo púdico-controladocivilizado/cuerpo disponible-desbordado-salvaje). Dicho de otra manera: aún resignificada a través del empoderamiento de "la guerrera" o "la heroína", la figura de "la madre popular" se presenta como "sola" o "soltera" (su sexualidad parece clausurada en pos de la crianza esforzada y decente de sus "huachos"). En esa medida, ella rinde cuentas sobre su sexualidad, confirmando con ello la sospecha de traición que pesa sobre el cuerpo femenino en el imaginario nacional.

La problematización feminista acerca de estos "cuerpos-metáfora de la nación" nos remite, por ejemplo, al trabajo de Jane Freedman, quien pensando en los símbolos y discursos políticos sobre la Libertad, la Justicia, la República, la Nación, etc., se preguntará: “¿Por qué si las mujeres se encuentran en los márgenes del poder político real, han sido elegidas por la iconografía para representar ese mismo poder?” (31). En esta misma línea, Elsa Dorlin y Catherine Achin (J’ai changé) han puesto el énfasis en las ansiedades que históricamente han marcado el cuerpo femenino como amenaza para el orden político: son los cuerpos masculinos los que encarnarán "el cuerpo legítimo", "el cuerpo verdadero", sin necesidad de representar nada más que a sí mismos. Los cuerpos femeninos, en cambio, serán "cuerpos alegóricos", abstractos, significantes de lo político y de sus valores. Por su parte, Varikas $(2006,2007)$ sostendrá que definir los cuerpos de las mujeres constituye uno de los núcleos discursivos tanto del colonialismo como de los nacionalismos modernos, en la medida en que de esos cuerpos-territorio dependen en gran parte la construcción y representación de la virilidad y de las jerarquías sociales. Junto con ello, para presentarse como unificada, pura y legítima, la idea de "nación" supone argumentos pre-políticos (la naturaleza, el territorio, la lengua, la tradición) que en general operan como metonimias de "la mujer". En suma, sostiene Varikas, los "cuerpos-metáfora de la nación" representan, pero no hablan en primera persona.

En Chile, el rendimiento nacionalista de "la madre popular" depende de esta operación ambivalente a través de la cual los cuerpos concretos y heterogéneos de las mujeres desaparecen en pos de una figura femenina "abierta", victimizada por el abandono del "padre popular" o del "extranjero" y luego "cerrada" e idealizada tanto a partir del sacrificio ("criar sola a su huacho") como a partir de una etérea y reificada "soltería". A su vez, esta situación señala y reclama el lugar vacío del padre, llamado ante el cual responderá la presencia heroica y protectora del Estado-nación.

Con respecto a este último punto, avanzaré una tesis que no podré demostrar a cabalidad aquí, pero que resulta indispensable al momento de historizar mis propuestas 
de lectura tanto de las representaciones nacionales de "la femineidad latinoamericana", como de las performances marianistas mistralianas en cuestión.

Los relatos nacionalistas que marcaron la época en la que vivió Mistral, podrían ser leídos como una reacción a las teorías raciales europeas y estadounidenses del siglo XIX que sostuvieron "la degeneración racial del mestizaje latinoamericano" (Leys Stepan 1991; Graham 1990). Si a este diagnóstico pesimista que ponía en riesgo las posibilidades de progreso y consolidación de los Estados latinoamericanos, las intelligentsias decimonónicas respondieron con políticas públicas pro-blanqueamiento y reforzamiento de la inmigración europea, a comienzos del siglo XX esta estrategia se verá tensionada por diversas retóricas antiimperialistas que pondrán en cuestión la superioridad racial del "blanco" y rechazarán la "penetración” política, económica y cultural de Estados Unidos y Europa (Graham 1990; Vera 2012). En ese marco, el uso nacionalista de la categoría "mestizaje" intentará responder a las expectativas de homogeneidad deseadas a partir del llamado a la definición identitaria y a "la unidad latinoamericana" ${ }^{5}$, cuestiones necesariamente ligadas, en esta época, a la idea de la "unidad racial".

Por su parte, en el Chile de las primeras décadas del siglo XX, la ecuación higienista de los valores $[$ limpio $=$ sano $=$ bueno $=$ 'blanco'], se encargará de construir el estereotipo de "la madre popular", representada como cuerpo femenino, morena, pobre, ignorante, sucia, supersticiosa, apática, sexualmente disponible y "mala madre" -es decir, responsable de las vergonzosas tasas de mortalidad infantil, características de un "país subdesarrollado" - (Lavrín 1995; Illanes 2007; Vera 2012). En tanto cuerpo sexuado resistente al progreso, "la madre popular" reitera la amenaza del pasado colonial marcado por la derrota frente al conquistador "blanco". Es apelando a esa escena mítica, que el Estado se presenta a sí mismo como el "buen padre" que vendrá a reemplazar tanto al "padre extranjero", indolente y abstracto como al "padre popular", alcohólico y sexualmente desenfrenado. Esta nueva paternidad promete proteger a "las madres de la raza" (incluso de su propia ignorancia e inmoralidad intrínsecas) y dar un futuro y un nombre legítimo a los "huachos" de la nación (Vera 2012).

En esa tarea, el Estado-nación apelará además al protagonismo de las mujeres que ya comenzaban a habitar decididamente el espacio público chileno: maestras, asistentes sociales, sufragistas. Entendiendo la oportunidad histórica que aquello significaba, gran parte de estas mujeres se organizó en torno a la inquietud de definir aquello que "la especificidad femenina" podría aportar en "la regeneración nacional".

5 La palabra "América Latina" es ya controvertida en estos términos. Aunque su "paternidad" ha sido tradicionalmente atribuida a Michel Chevalier (en el contexto de la intervención francesa en México en 1862), el filósofo uruguayo Arturo Ardao (1990) ubica y destaca -alrededor de 1850- los orígenes "hispano-americanos" del término, apuntando al pensamiento decimonónico de intelectuales como José María Torres Caicedo y José Martí. En todos los casos, Ardao sostiene que en la época de su emergencia, los términos "América-Latina" o "Latinoamérica" constituyeron la primera idea de una "unidad latinoamericana" frente a una "América anglosajona" (46). En este sentido, la idea de una "latinidad americana" parece resultar menos de la fe en una comunidad compartida que en la necesidad de asistirse mutuamente frente a las amenazas que representaban Estados Unidos y Europa. 
Es por esto que fue común que los intereses de las feministas y de las primeras mujeres profesionales se correspondieran con los de "la maternidad científica" puericultural (Lavrín 1995). A cambio, las mujeres exigirán derechos civiles y políticos.

Es bajo los términos de esta "buena femineidad nacional" que se jugarán las oportunidades redentoras de las "huachas de excepción” como Gabriela Mistral.

\section{Excepcionalismo: "huellas parias" de la modernidad}

Varikas (2007) propone la figura del "paria moderno" como una "metáfora viva" capaz de hacer hablar las tensiones y contradicciones de la modernidad, época en la cual se construyó "la diferencia" como marca de nacimiento y "la igualdad" como un privilegio que es necesario demostrar merecer.

Hannah Arendt ha descrito las contradicciones vividas por uno de estos parias modernos nacidos del "mal lado del universal" (Varikas Les rebuts 59): los judíos. Particularmente, Arendt se referirá a "los judíos de excepción” (aquellos que en tanto grandes intelectuales o comerciantes lograron 'asimilarse' en los diferentes países en los que vivieron antes del holocausto nazi) como personas "incapaces... de hacer la diferencia entre un cumplido y un insulto" al sentirse halagados cuando un antisemita les decía que él no los englobaba en su antisemitismo, ya que ellos eran "Judíos excepcionales" (La tradition 124). Efectivamente, negándose al destino de la exclusión, algunos parias modernos se tomaron en serio "la buena nueva de la asimilación" ( $\mathrm{La}$ tradition 179) y optaron por el excepcionalismo como escapatoria y entrada individual al "mundo refinado" de la igualdad (Les rebuts 55). Entre ellos, "las mujeres de excepción", cuyo estatuto existencial deviene paradójico:

En la medida en que el ser humano libre es de entrada y por definición situado en las antípodas del ser mujer, acceder a ese estatuto sólo es posible a partir de un esfuerzo constante y sistemático de diferenciación en relación al género de las mujeres ...: 'yo no soy como todas las mujeres' ... La arrogancia con la cual 'la excepción admitida' devuelve a sus semejantes a la regla de exclusión, la aceptación de los valores dominantes que la conduce a desolidarizarse de los miembros de su género: he aquí las garantías que la mujer excepcional parece deber dar a la sociedad patriarcal (Riot-Sarcey y Varikas, Réflexions 82-6, énfasis de las autoras).

En efecto, rompiendo la regla de exclusión de las mujeres de manera individual, "la excepción" confirma la regla de exclusión de las mujeres en tanto género.

Desde un punto de vista que intenta superar la posición resignada según la cual estas mujeres "no habrían tenido otra alternativa", me interesa más bien problematizar la serie de contradicciones que han marcado estas experiencias históricas de "excepcionalidad". Me refiero a aquello que Riot-Sarcey y Varikas han llamado "la 
excepcionalidad subjetivamente vivida": "el sentimiento alienante de ser una anomalía, un ser híbrido que no pertenece a ningún grupo, acecha los escritos femeninos y feministas... [y] a menudo está en el origen de los caminos tomados por la afirmación de sí" (Réflexions 79-80).

Efectivamente, aunque la "conciencia de excepción" (Riot-Sarcey y Varikas, Feminist 452) de muchas de estas mujeres impide su total asimilación a los valores dominantes, no logra impedir en cambio las contradicciones y ambivalencias: los vaivenes entre humildad y arrogancia, entre visibilidad e invisibilidad, la compulsión meritocrática, la enorme inversión de energía y de talento para "justificar el mero hecho de su existencia" (Arendt, Rahel 285), el esfuerzo por disimular una "tara imaginaria" (Arendt, La tradition 73), la "insoportable sensación de estar todo el tiempo expuesta" (Rahel 272), "condenada a la originalidad" (La tradition 43), de mentir e intentar todas las máscaras, "todos los disfraces" (La tradition 73), los sentimientos de culpabilidad y la necesidad de recompensar la transgresión restableciendo "a los ojos de los hombres la conformidad con la imagen normativa de lo femenino" (Réflexions 84).

En efecto, "la mujer de excepción" entiende que de alguna manera "ha robado algo" y en esa medida, generalmente apela a la neutralización o a la negación ritual de la importancia de sus actos: "renegar por una extrema humildad el alcance de su transgresión...es una actitud que se encuentra en un buen número de mujeres escritoras célebres" (Réflexions 84). Sin embargo, pagando "el precio de la gloria social con una miseria política” (Rahel 162), se produce una inversión curiosa: finalmente, "es la condición invivible de su estatus de excepción lo que la acerca a 'la mujer ordinaria': la soledad de esta condición, la imposibilidad de pertenecer, la obligación de estar expuesta a la desconfianza de hombres y mujeres..." (Réflexions 84).

Delphine Dulong y Frédérique Matonti (2005), por su parte, han pensado en el caso de las mujeres políticas y en la excepcionalidad como marca paradójica en el cuerpo. En efecto, en la medida en que el cuerpo legítimo en el espacio político es masculino, éste escapa a la mirada objetivante de los otros, lo que le permite holgura y gracia. Y aunque el requisito para la participación de las mujeres políticas es que "permanezcan femeninas" o si las mujeres políticas deber ser ante todo "mujeres", tampoco deben serlo tanto. Se trataría de una femineidad paradójica, siempre en proceso de llegar a ser: ni demasiado masculino, ni demasiado femenino, el cuerpo de las mujeres políticas nunca es el correcto.

En la misma línea, Riot-Sarcey y Varikas identifican la tendencia de "la mujer de excepción" a la neutralidad, al trasvestimiento y a la ambigüedad. Queriendo pertenecer a "la humanidad en general", ella "deviene, de alguna manera, no un 'simple ser humano, sino que un hombre honoris causa” (Réflexions 83).

Quizá es por todo lo anterior que, en los estudios feministas, la noción "máscara” posee ya una tradición. Uno de los hitos al respecto corresponde al texto que la psicoanalista Joan Rivière escribe en 1929, "Womanliness as a mascarade”, y que será re-trabajado por Judith Butler al momento de pensar la performatividad del género. 
Reflexionando sobre algunas de sus pacientes, fundamentalmente mujeres intelectuales o que tenían mucho éxito en su trabajo, Rivière afirma que luego de demostrar públicamente su capacidad intelectual (la exhibición del pene del padre), estas mujeres se sentían presas de un terror espantoso frente al castigo que se les impondría. Para tranquilizarse, adoptaban actitudes seductoras compulsivas, simulando ser mujeres castradas o criaturas inocentes e inofensivas:

la femineidad, por lo tanto, podía ser asumida y utilizada como una máscara para ocultar la posesión de la masculinidad, así como para evitar las temidas represalias que se tomarían contra ella si esto se llegara a descubrir; al igual que un ladrón vacía sus bolsillos y pide ser registrado para demostrar que no ha robado nada. El lector podrá tal vez preguntarse ahora cómo defino la femineidad o dónde trazo la línea que separa la genuina femineidad de la "máscara". Sin embargo, mi opinión es que no existe tal distinción; ya sea de manera radical o superficial, son una misma cosa (Rivière 221, el énfasis es mío).

Es esa última frase la que llamará la atención de Butler en El género en disputa. Efectivamente, afirmando que no existiría distinción entre la "femineidad auténtica" y la "femineidad mascarada", Rivière parece sugerir no solamente que toda identidad femenina tendría una relación directa con la gestión de la angustia, sino que la femineidad podría ser comprendida siempre como mascarada, una teatralización compulsiva que tendría por objetivo evitar las represalias y ocultar la igualdad con los hombres.

Otro texto luminoso al momento de problematizar la cuestión de la máscara, corresponde a "Las tretas del débil", de Josefina Ludmer. El sujeto a analizar es paradigmático para las "mujeres de excepción" latinoamericanas: la poeta y dramaturga de la Nueva España del siglo XVII, Sor Juana Inés de la Cruz. Específicamente, su "Respuesta a Sor Filotea", escrita en $1691^{6}$. Ludmer analiza la respuesta de Sor Juana en estos términos:

Saber y decir, demuestra Juana, constituyen campos enfrentados para una mujer; toda simultaneidad de esas dos acciones acarrea resistencia y castigo...En este doble gesto se combinan la aceptación de su lugar subalterno (cerrar el pico las mujeres) y de su treta: no decir pero saber, o decir que no sabe y saber, o decir lo contrario de lo que sabe. Esta treta del débil, que aquí separa el campo del decir (la ley del otro) del campo del saber (mi ley) combina, como todas las tácticas de resistencia, sumisión y aceptación del lugar asignado por el otro, con antagonismo y enfrentamiento, retiro de colaboración (48-52).

6 Ludmer nos recuerda que "Sor Filotea " fue el pesudónimo utilizado por el obispo de Puebla para escribir a Sor Juana. El obispo había publicado anteriormente un texto polémico de Sor Juana bajo el título de "Carta Atenagórica". En este texto teológico, Sor Juana se permitía interpretar y criticar un sermón de Antonio de Vieyra a propósito de "las finezas de Cristo". 
Por su parte y pensando en la máscara como una imitación vehiculizada por la necesidad del reconocimiento del otro, Dorlin propone vincular la idea de "la performatividad del género" de Butler al concepto “imitación colonial” de Homi Bhabha (2007), quien a su vez se inspira en la idea de "máscara" de Frantz Fanon (1952). Esto, con el objetivo de pensar la lógica común entre racismo y sexismo:

La imitación...puede ser comprendida como una técnica de poder que apunta a encerrar al colonizado en la identidad deshonrosa que lo caracteriza: la identidad prescrita que representa el estereotipo se transforma entonces en la identidad que el colonizado está obligado a imitar para existir, a representar para ser reconocido (Dorlin, Performe, el énfasis es mío).

Finalmente y considerando la noción "máscara" como antecedente, quisiera detenerme en el concepto performance, elaborado por Judith Butler en El género en disputa. La autora sostiene que el género ha sido pensado, dentro de una relación heteronormada de estabilidad sistémica sexo-género-sexualidad, como la representación causal de la verdad del sexo: es decir, el género se presenta como significación exterior de la verdad anatómica del sexo. En estos términos, el género aludiría a un campo de representación visual que Butler propone analizar utilizando un concepto cuyos orígenes podemos encontrar en el teatro: performance. Según el análisis de Butler, la performance del género aludiría a un proceso de repetición regulado, a prácticas sociales ritualizadas a partir de las cuales nos marcarnos a nosotros mismos como "hombres" o "mujeres". A partir de estos actos performativos, yo no expreso mi identidad, sino que la produzco al momento en que la ejecuto, no ceso de interpretarla. El género sería entonces una relación en acto, pero que precisamente se oculta como relación social (Dorlin, Performe).

Es a partir de este concepto vinculado a la estrategia del excepcionalismo, que propongo entender las figuras marianistas en Mistral.

\section{"La Maestra de América Latina" y "La poeta redentora": performances marianistas en Gabriela Mistral}

Propongo la noción performance marianista en tanto teatralización ritualizada de la femineidad latinoamericana de excepción, basada en una representación maternal racializada, heroica y ascética del cuerpo femenino que implica la negación o sublimación de la sexualidad. La performance marianista expresaría así, una "relación en acto" con los nacionalismos latinoamericanos.

En el presente texto, no podremos abordar ni desarrollar el potencial subversivo de la performance ${ }^{7}$ marianista en Mistral (el que localizo fundamentalmente en una

7 Recordemos que según Butler, en la performance de género anidan sus propias posibilidades de subversión ya que aquellos contextos que instituyen al sujeto como sujeto atado o subjetivado, son justamente las instancias que le 
parte de su poesía -ésa que se manifiesta como "adversaria de la prosa" (Rojo, Dirán 466) - y en sus cartas de amor a Doris Dana). Nos focalizaremos, en cambio, en el uso estratégico (no necesariamente subversivo) de esta performance a partir del problema político del "excepcionalismo".

Representante de ese "monstruo moderno" que fue (es) la mujer-escritora y política (Varikas Les rebuts 67), Mistral encarna el estatuto paradojal de la "excepcionalidad".

En efecto, la "excepcionalidad mistraliana" fue enunciada de diversas formas mientras Lucila Godoy vivía: "la pluma viril”» (Julio Molina, cit. en Subercaseaux 98), "la divina Gabriela Mistral" (Virgilio Figueroa)", "Santa Gabriela Mistral" (Benjamín Carrión) ${ }^{10}$, "María de Nazareth" (Pedro Prado, cit. en Horan, Santa 22), "la gran cantante del dolor y la maternidad" (Gullberg, Award Ceremony Speech).

Tales imágenes nos hablan de las expectativas y ansiedades de género de un imaginario nacional que, al momento de pensar en un modelo de heroísmo femenino al interior del cual poder localizar y reconocer la figura excepcional de Mistral, propone representaciones religiosas y maternalistas.

Elizabeth Rosa Horan subraya que aunque el de maestra fue un trabajo que Mistral ejerció sólo entre 1909 y 1918, su eficacia simbólica dependería de una iconografía mayor de la santidad que muchas veces se muestra claramente marianista. Esta representación virginal de Mistral permitiría resolver "uno de los problemas centrales del nacionalismo moderno: cómo representar, o incluso reconocer a mujeres individuales, históricas, dentro de la fraternidad vasta y horizontal de la ciudadanía nacional" ("Santa" 22).

Estableciendo una comparación entre Mistral y Sor Juana Inés de la Cruz, Horan se propone seguir "la narrativa de la santidad" que atravesó el discurso de ambas mujeres en tanto "ministras de Dios o de la Educación" ("Sor Juana” 90). Según la autora, la representación de la santidad "fue un hábito y una armadura, una máscara y un uniforme" ("Sor Juana” 92) utilizados en un marco sociopolítico hostil. Este estilo hagiográfico invocará la vida de los santos como defensa frente a los ataques de críticos y rivales, apelando "a la importancia y valor de las mujeres fuera del ámbito

pueden permitir subvertir la ley. El potencial subversivo de la performance de género dependería entonces, de citaciones descontextualizadas de la ley, es decir, de citaciones de la ley en un contexto no autorizado, no legítimo. A partir de ello, se evidenciarían los procesos de naturalización por los que se produce la normalidad.

8 Es interesante subrayar los vínculos entre nacionalismo y literatura criollista, a partir de los cuales la escritura de ciertas "mujeres de excepción" fue halagada con este adjetivo curioso: "viril". Armando Donoso caracterizó "la escritura viril" así: "se trata [...] de utilizar 'la palabra clara y precisa', sin ornamentos, de tener la capacidad de ver 'lo que hay detrás de las apariencias, detrás de los maquillajes y los cosméticos"” (cit. en Subercaseaux 98). $\mathrm{Al}$ respecto, Subercaseaux consigna que existía en esta época una división entre los poetas "viriles, vernaculares y criollistas" y la literatura "feminizada", representada por la poesía moderna, decadente y de un aristocratismo patológico. Así por ejemplo, Mariano Latorre dividirá la literatura chilena en dos: "los escritores-recipientes" (que imitan a los autores extranjeros) y los "escritores-vertientes" (que generan obras a partir de ellos mismos). El autor feminizaría a los primeros y virilizaría a los criollistas.

9 Nombre de su libro, publicado en 1933 por la imprenta "El Esfuerzo".

10 Nombre de su libro, publicado en 1956 por la Editorial Casa de la Cultura Ecuatoriana. En él, el autor sostenía: "la santidad de Gabriela Mistral es una santidad activa. Todas esas santidades confluyen en la maternidad suma, de la que ha hecho la profesión de su vida: la santidad de la Maestra" (Carrión, cit. en Horan, "Santa" 30) 
sexual, en la esfera pública” (“Sor Juana” 98, el énfasis es mío). Así, en esta máscara "cuidadosamente codificada", sufrimiento, persistencia, humildad, renuncia y autodenigración permitirán vincular las propias experiencias al dolor y a los obstáculos atravesados por Cristo, representando con ello, la victoria y el heroísmo femenino.

Horan señala, por ejemplo, la prosa de Desolación, deteniéndose en "Oración de la maestra”: "Dios mío! Tú que enseñaste, perdona que yo enseñe, que lleve el nombre de 'maestra' que tú llevaste sobre la tierra!" (Mistral cit. en Horan "Sor Juana" 91); o en "Voto", el texto en el que Mistral pide excusas por Desolación, como quien pide perdón por hacer algo demasiado grande: "Dios me perdone este libro amargo y los hombres que sienten la vida con dulzura, me lo perdonen también” (cit. en Horan "Sor Juana” 91).

Como lo hemos sostenido, el cuerpo sexuado de las mujeres perturba el espacio público y el imaginario nacional, cuestión que a su vez moldea las auto-representaciones de las "mujeres de excepción" que les permiten hablar en primera persona. En este caso, "el pago del tributo" apunta a una práctica discursiva auto-vejatoria.

Horan señala que muchos de los "relatos oficiales" sobre la vida de la escritora también portarán un "carácter hagiográfico", destacando las cualidades de austeridad, obediencia, timidez, modestia y virtud para rezar de la joven Lucila, su "inclinación a la soledad" o sus diálogos infantiles y franciscanos con lagartijas, flores y árboles (Horan, "Santa" 28). Según la autora, son ciertas ansiedades nacionales las que habrían estado a la base de esta iconografía: "la construcción narrativa de 'la divina' responde a la excentricidad de un sujeto cuya vida real amenazaba constantemente el decoro femenino y contradecía la masa de estereotipos sobre "la chilena" ("Santa" 27).

Según Horan, la comparación de Mistral con la Virgen se intensificará una vez la poeta muerta, ocasión descrita por las cronologías de la época como "apoteosis":

La 'apoteosis' sugiere que el cuerpo es el obstáculo para reconocer a las mujeres como ciudadanas. El Rector de la Universidad de Chile honró este problema del cuerpo cuando su elogio le otorgó el interesante, anómalo y casi asexuado título de 'doctora angélica'... El cuerpo femenino grueso, real de Gabriela Mistral, con su piel morena, habitual ceño fruncido, y zapatos talla 40, plantea un problema a la tendencia de la iconografía nacionalista, a admitir la figura femenina sólo en representaciones alegóricas como 'Libertad', 'Justicia', y 'Maternidad Republicana'. La Virgen, en contraste, es una figura de la victoria tanto sobre el sexo como sobre la muerte... Un heroísmo que surge de su negación del cuerpo y de la anulación o sublimación de su sexualidad ... La muerte hace de su ... incorruptible cuerpo, un símbolo del pasado remoto, rural y heroico de la nación ... Identificar a Gabriela Mistral con la pasión privada y la emoción por sobre la intelectualidad y la razón es central en cómo la hagiografía sirve a los intereses nacionalistas, reduciendo las vidas de las mujeres (pero no las de los hombres) a términos morales y sexuales ... Dentro de las categorías primarias -virgen, mártir, confesor- ningún hombre es descrito como virgen y ninguna mujer como confesora" (Horan "Santa” 23-9, el énfasis es mío). 
Desde esta demanda de género del discurso nacionalista, problematizaré a continuación la respuesta estratégica de Mistral a partir de dos performances marianistas: "la Maestra de América Latina" y "la Poeta redentora".

\section{"La Maestra de América Latina"}

Diversas lecturas críticas coinciden en problematizar la auto-representación maternalista de "la Maestra" en Mistral. Así por ejemplo y analizando fundamentalmente su prosa, Ana Pizarro (1990) sostendrá que Mistral usa esta máscara para autorizarse a sí misma a una posición enunciativa universal y al mismo tiempo, calmar las ansiedades del lector, asumiendo a priori una posición subalterna de reproducción y no de producción discursiva. Nicola Miller, por su parte, afirma que Mistral manipula su propia imagen, ocultando la rebelión "tras la máscara de la profesora de escuela" (145). Focalizándose en el análisis de su obra poética, Lila Zemborain sostiene que "las auto-representaciones de Mistral como 'mujer estéril' y como 'madre espiritual' encubren a la mujer que opta por no tener hijos" (84). Para Fiol-Matta, en cambio, "la mascarada de la maternidad" constituyó para Mistral "el clóset ideal” de su lesbianismo (The Schoolteacher 206). Tace Hedrick agrega que en tanto maestra, Mistral produce una auto-representación de sí misma como encarnación del "proyecto modernizador del mestizaje” (84). Grínor Rojo, por su parte, sostiene que el énfasis no debe ser puesto en el binarismo autenticidad-inautenticidad, sino que en las diferentes naturalezas de los "simulacros y mascaradas" mistralianas (Summa) y en las condiciones de recepción y selección de la crítica literaria de su época.

Mi propuesta consiste en problematizar la figura de "la Maestra de América Latina" en tanto performance marianista, a partir de tres claves: la excepcionalidad sexual, la excepcionalidad racial y la excepcionalidad de género de "la buena femineidad civilizatoria”.

En primer lugar, la performance marianista de "la Maestra de América Latina" puede ser pensada desde su excepcionalidad sexual, es decir, a partir de la figura de "la rara".

Tanto Oyarzún como Horan sostienen que es el libro Desolación el que concita la mayoría de las insistentes representaciones de Mistral como "la abandonada" o "la madre frustrada", las cuales iniciarán "la larga fantasía del amor heterosexual" (Horan, "Santa" 29) como eje interpretativo de la poesía mistraliana por parte de la crítica chilena. Horan sostiene que el pánico nacionalista heterosexista conjura la soltería, la independencia intelectual y económica de Mistral en una iconografía en la que la preocupación por los niños y la reverencia por la maternidad serán centrales.

Fiol-Matta avanza más allá del pánico a la independencia intelectual y económica, al sostener que la fantasía nacional en torno a la heterosexualidad de Mistral coexistió con el latente "secreto a voces" de su lesbianismo. Así, la autora partirá por destacar algunos de los estereotipos de "la maestra" en Latinoamérica: "la solterona", la mujer 


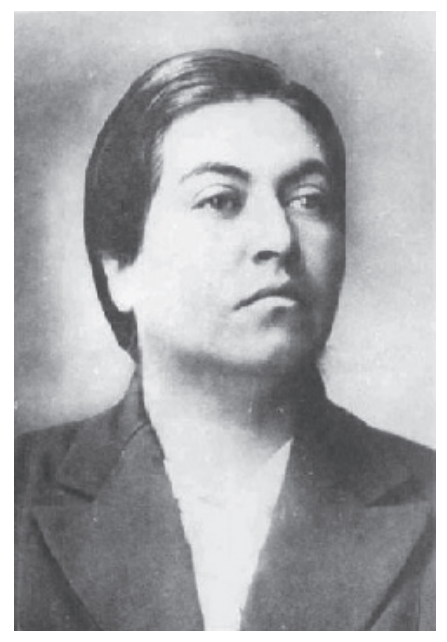

Figura 3. Gabriela Mistral, 1922. Archivo del escritor - Memoria Chilena. (portada del libro de Licia Fiol-Matta, "A queer mother for the nation").

"reprimida", "frígida", "hispersexualizada" o lesbiana. Efectivamente, estas mujeres parecen "raras" desde cualquier punto de vista. De ahí que Fiol-Matta se pregunte: ¿por qué el Estado chileno habría elegido a una mujer "lesbiana" como guardiana de "la familia nacional"? En efecto, el éxito de Mistral como encarnación del proyecto nacionalista podría parecer extraño si consideramos su significativa distancia con la conducta y apariencia femenina aceptables en la época.

Sin embargo, considerando que los "requisitos morales" del magisterio eran definidos por los Estados latinoamericanos, Fiol-Matta afirmará que la figura de "la maestra" es "mandatadamente rara" y que es la simultánea negación del lesbianismo de Mistral junto a una fascinación anclada en un "deseo nacional de saber", el escenario en el que se juegan sus máscaras. Así y aunque Fiol-Matta asevera un nivel de autoconciencia en Mistral que yo me atrevería a cuestionar, su lectura es estimulante: la autora sostendrá que Mistral era consciente de los efectos de su "rareza", de su ambivalencia masculino-femenino y del uso político que podía hacer de aquello. Y sería justamente esa "rareza exótica" la que será aprovechada tanto por el Estado como por Lucila Godoy en la producción del ícono "Mistral”. En efecto, Fiol-Matta sostiene que es esta ambivalencia la que hará de Mistral un ícono susceptible de identificación nacional: siempre incompleta, siempre perfectible, siempre en suspenso (A queer). (Figura 3)

La figura de "María, excepcional entre todas las mujeres", también parece depender de una "rareza sexual": su condición de madre inmaculada.

Para la teóloga queer Marcella Althaus-Reid "las narrativas de copulación divina" (92) tienen consecuencias reales en las biografías de nuestros países latinoamericanos. Según la autora, la escena de "teología androide" de la concepción de Cristo, nos presenta la copulación entre un "Dios-máquina" que copula bajo la forma de una 
especie de "nube divina" (106) con una María pasiva y "protoalienígena” (106) que "concibió al inhalar el aroma del semen del Padre" (109). Así, "la heterosexualidad de armario" (71) del catolicismo marianista dependería de la figura de una "mujer sin vagina” (61): "María máquina”, María aparato-raro (55).

La sexualidad "en suspenso" de la performance mistraliana de "la Maestra" es en gran medida coherente con el "ícono del himen pétreo" mariano (115), que AlthausReid criticará justamente por su falta de relación con las vidas concretas de las mujeres populares latinoamericanas.

En esta línea, también resulta interesante destacar la misteriosa maternidad mistraliana (sin relación sexual mediante) de su hijo suicida, Juan Miguel Godoy y junto con ello, la distancia entre su vida lesbiana y su mensaje de "reproducción nacional" dirigido a "las madres de la raza". Así podemos constatarlo en "Lecturas para Mujeres"11, texto en el que Mistral sostenía: "Para mí, la forma del patriotismo femenino es la maternidad perfecta. La educación más patriótica que se da a la mujer es, por lo tanto, la que acentúa el sentido de familia. El patriotismo femenino es más sentimental que intelectual..." (xvi, énfasis de la autora). De manera similar, en "Algo sobre higiene social en la América hispana", escrito en 1926, Mistral propondrá un concepto "más objetivo que abstracto de la raza": el "patriotismo biológico" que debería orientar las acciones higienistas. Así y como en varios de sus textos en esta época ("Sobre la mujer chilena", "A la mujer mexicana", etc.), la idea moderna del patriotismo maternal biológico se presenta en Mistral como un discurso pedagógico y asimétrico: son "otras" y no ella, las encargadas de reproducir "la raza".

La performance marianista mistraliana articula estos significados encarnados en un cuerpo maternal y atávico, pero cuya sexualidad se presenta inaccesible. A partir de este cuerpo alegórico, "la Maestra de América Latina" puede posar como "casada con la causa nacional [por la que] habría sacrificado su satisfacción personal, por el bien de ella y de los 'hijos nacionales' del Estado, los ciudadanos" ( $A$ queer 6).

Una segunda manera de leer la figura de "la Maestra de América Latina" en tanto performance marianista, alude a su "excepcionalidad latinoamericana" como "mestiza".

Fiol-Matta sostiene que aunque la obra y la figura de Mistral hayan sido olvidadas o descuidadas por mucho tiempo, es imposible desmentir el hecho de que la poeta fue una de "las principales arquitectas del nacionalismo latinoamericano" (A queer xiii).

Como hemos sostenido, una característica central de estos nacionalismos en la primera mitad del siglo XX, corresponde a la defensa del mestizaje como "excepcionalidad", "expresión de identidad", "mesianismo latinoamericanista" (Castro-Gómez 1996) y, en la voz del Estado-nación, como posibilidad de asimilación de los indíge-

11 Libro escrito y publicado en 1924 por encargo del gobierno mexicano con el objetivo de agrupar una serie de lecturas apropiadas para "la mujer americana". 
nas (Graham 1990; Vera 2012). En términos generales, se asentará la idea binaria de una Europa envejecida v/s una Latinoamérica joven y revitalizada por el mestizaje, a partir de lo cual el continente tendría "la misión de hacer avanzar al mundo hacia una cultura 'unitaria e integral"', inclusive hacia una nueva "eticidad" (Castro-Gómez 81).

Uno de los representantes paradigmáticos de este tipo de retórica, fue el mexicano José Vasconcelos, quien para 1922 fuera el Ministro de Educación que invitara a Mistral a participar de la reforma educacional del país: los biógrafos de la poeta coincidirán en que es a partir de este hito que su carrera adquiere un ascenso internacional. Pensador clave del mestizaje latinoamericano (al que hizo referencia bajo el mesiánico nombre de "la raza cósmica") y del "rol apostólico" del magisterio orientado a la educación y asimilación de los indígenas, la figura de Vasconcelos parece haber influido en la auto-representación de Mistral como "la Maestra mestiza".

En efecto, para autoras como Fiol-Matta, parte de la eficacia del ícono "Gabriela Mistral" dependerá del hecho de que la poeta no se contentó con representar el ideal de la femineidad "blanca" de clase media ilustrada chilena, sino que apeló a una identificación continental: "la Maestra de América Latina”, ícono heterosexual y símbolo del mestizaje latinoamericano: "Mistral ofreció su propio cuerpo como la representación de un raza entera, una raza creada de una tradición inventada... [Ella alcanzó] el estatus de guardiana simbólica de la familia nacional” (A queer 4-5).

El recurso identitario a la categoría racial "mestizaje" es problemático, tal como señalábamos en la crítica de García de la Huerta a la idea de "la síntesis cultural mestiza" defendida por Montecino. Justamente, uno de los conflictos internos de este discurso apunta a la relación mestizo-indígena. Esto constituye justamente el eje de la reflexión de Patricia Rubio, quien sostiene que la crítica ${ }^{12}$ ha tendido a destacar el "indigenismo de Mistral" de manera unívoca y complaciente, sin problematizar ni su uso de la noción "raza" ni la lógica de los "buenos" y "malos" mestizajes que subsiste en sus aseveraciones con respecto a los "diferentes grados de desarrollo" de los diversos "grupos raciales" (25). Según la autora, se trata de ambigüedades que no son exclusivas del discurso mistraliano sino que características del "pensamiento indigenista tanto mexicano como peruano -sobre todo de la primera mitad de siglo [XX]" (26). Mistral adherirá, entonces, a lo que "ella cree ser un proyecto incluyente, el mestizaje" (40) bajo la forma mestizofílica y la urgencia alfabetizadora de Vasconcelos.

Algunos de los tópicos claves de esta ambivalencia del pensamiento indigenista "mestizofílico", conciernen la exaltación de "la herencia biológica" (la localización del "indígena" en un pasado puro e incorpóreo) y "la belleza del indio":

12 La necesaria atención a las tensiones que constituyen la vida y obra de Mistral me anima a sugerir la lectura de Soledad Falabella ¿Qué será de Chile en el cielo? Poema de Chile de Gabriela Mistral. (Santiago: LOM, 2003) como una de las buenas defensas de "la Mistral indigenista". Una lectura más crítica de Poema de Chile es la de Mary Louise Pratt: "Women, Literature, and National Brotherhood". Women, Culture, and Politics in Latin America. Seminar on Feminism \& Culture in Latin America. Berkeley: University of California Press, 1990. 48-72. 




Figura 4. La reina de la fiesta. Señorita María Letelier del Campo. El libro de los Juego Florales, 1914. Archivo del escritor. Memoria chilena.

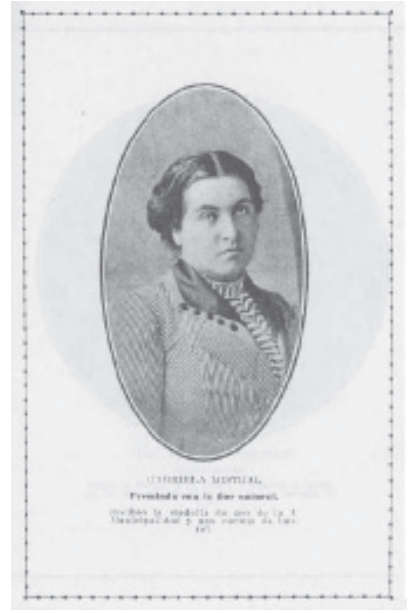

Figura 5. Gabriela Mistral. Premiada con la flor natural. Recibió la medalla de oro de la I. Minicipalidad y una corona de laurel. El libro de los Juego Florales, 1914. Archivo del escritor. Memoria chilena.

Cojan Uds. la mejor nariz indígena, y cojan Uds. la talla del patagón y tomen algunos ojos de indio en los cuales el negro es tan profundo, la mirada tan entrañable... y tomen Uds. unos cuantos rasgos más y verán la hermosa escultura racial que tendríamos y qué contentos estarían todos los mestizos que reniegan su indio, de decir, '¡yo soy ese!' (Mistral, cit. en Rubio 39).

La reivindicación del "mestizo eugenésico vasconceliano" (Leys Stepan 153) y la definición del "indígena" como pasado espiritual y del "mestizo" como futuro nacional, hacen parte de las contradicciones del discurso asimilacionista del mestizaje.

Pero para Fiol-Matta, el criterio de "la belleza" y "la fealdad" que opera al interior de estas clasificaciones raciales, tiene un alcance mayor: lo que estaría en juego sería, nuevamente, la máscara de "la rara" a partir de la cual Mistral se presenta simultáneamente como "mestiza" y "fea especial". (Figura 4 y 5)

$\mathrm{Al}$ respecto, la carta que Mistral le escribiera a su amigo demócrata cristiano Radomiro Tomic, llama la atención de Fiol-Matta:

Alessandri declaró a Vasconcelos, cuando yo estaba en México, 'el error suyo de haberme llevado allá, en vez de la A.L.H’ [Amanda Labarca Hubner]. Y en el banquete que le dio luego, se la presentó, insistiendo en lo mismo y sentándosela al lado. Al irse, Vasconcelos le dijo: -'De éstas tenemos en México, muchas y de más; pero la que me llevé es diferente y rara’. El me lo contaba riendo... (Mistral cit. en Vargas Saavedra 162, énfasis de Mistral). 


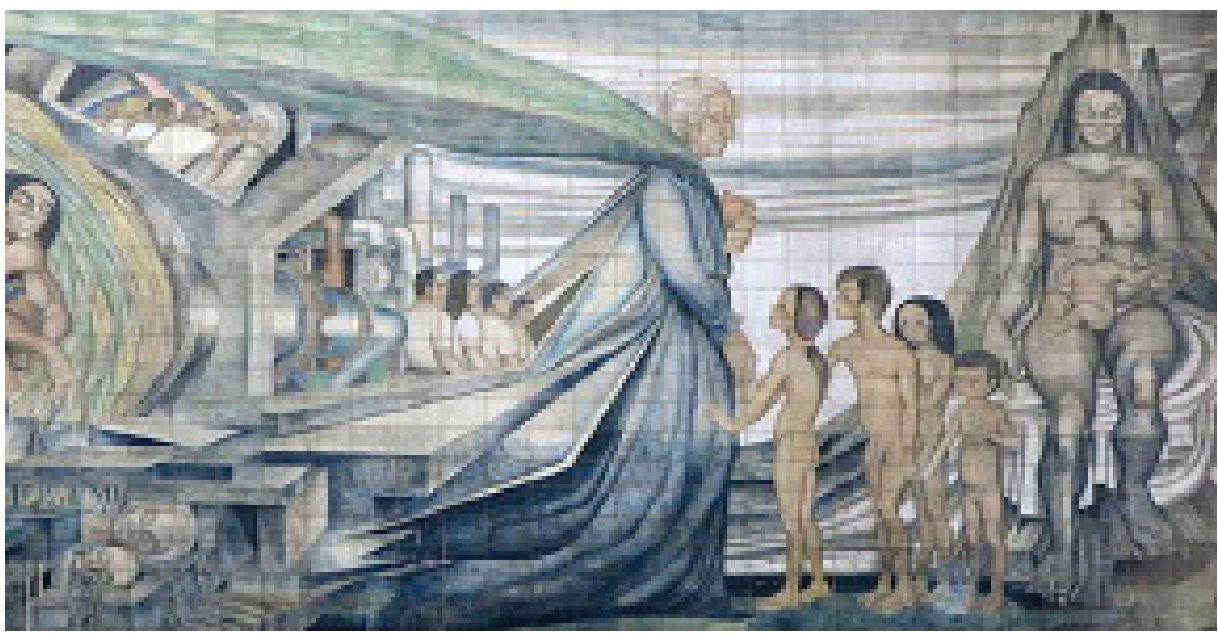

Figura 6. La ciudad de Santiago a Gabriela Mistral. Fernando Daza, 1970. Mural ubicado en el Cerro Santa Lucía.

Según Fiol-Matta, Vasconcelos habría visto que

había algo acerca de la inclusión de lo queer ${ }^{13}$ como un ser solitario e inaccesible que podría favorecer la inclusión simbólica del indígena en los mismos términos (...) Mistral ofreció un relato atractivo de moralidad: un objeto hermoso confundido con uno feo, un ícono milenario y singular fatalmente separado de la vida social, una rareza digna de una curiosa mezcla de lástima y admiración (10-1).

Así, Fiol-Matta sugerirá que la performance mestiza mistraliana operó como una compensación del racismo de Estado: Mistral ofrece su cuerpo en substitución de la madre indígena perdida.

En efecto, tanto la Virgen como "la Maestra" mestizas, constituyen fetiches del discurso latinoamericanista que "corrigen" el cuerpo sexuado y abierto de "la madre indígena" a través de un cuerpo femenino que, aun portando las marcas racializadas del pasado, es más bello, más puro y más civilizado...y en esa medida, sí merece la identificación nacional.

Finalmente, propongo problematizar la figura de "la Maestra de América Latina" a partir de la performance de "la Virgen-Maestra civilizadora".

El carácter civilizatorio de la "Virgen-Maestra" es notablemente destacado en el análisis de Rosa Horan del mural del cerro Santa Lucía, en el que Mistral aparece como "marcadora de límites, defendiendo visiblemente el fetiche de la diferencia nacional” (McClintock, cit. en Horan, “Santa” 34). (Figura 6)

13 Recordemos que aunque "queer" puede ser traducido en español -incluyendo la carga homoerótica de la palabracomo "raro/a", en inglés la palabra "queer" está marcada de manera mucho más nítida por el insulto, lo que la haría más cercana a la palabra "maricón/a”. 
Horan remarca la semejanza de esta obra con los grandes murales de la revolución mexicana, y señala en él las representaciones del

eterno pasado rural, asociado con la tierra y la pureza indígena; la maternidad encarnada, asociada con los Andes y los niños -la materia prima de la nación-y finalmente, el mundo de la industria, asociado con los ciudadanos-trabajadores homogéneos...Gabriela es la puerta para estos ciudadanos y el muro de la socialización hacia el cual marcha la fila de niños desnudos, lejos de su igualmente desnuda pero estática madre. En su postura de recibir a los niños, es como un papa o un Jesús, el status cuasi-religioso del educador se evidencia en el libro que ella sostiene en su mano izquierda, y en sus oscuras túnicas... De las quince figuras en el mural, sólo Gabriela Mistral no tiene ninguna marca de género, y sólo la madre no está comprometida en ninguna actividad que sea visible ("Santa" 34).

Tanto "la Virgen mestiza" como "la Maestra" son figuras civilizadoras y maternales que, después de la guerra, tienen por misión construir la paz entre todos aquellos que han sido antes enemigos.

Sin embargo, los efectos problemáticos del uso estratégico de esta "buena femineidad nacional" quedan bien evidenciados en esta jerarquización entre las madres "mestizas" y las "indígenas", las del presente activo y las del pasado incorpóreo, las representantes de la cultura y las de la naturaleza, las asexuadas civilizadoras y las que no son sino carne abierta.

\section{La Poeta redentora}

La obra poética de Mistral ${ }^{14}$ también nos abre un campo simbólico fructífero al momento de problematizar las figuras marianistas. Allí, es "la Poeta" la que se nos presentará como figura redentora.

En relación a la interpretación de la posición de esta figura en términos de género, uno de los debates interesantes corresponde al sostenido entre Jorge Guzmán y Patricio Marchant a mediados de los años ochenta. Sin posibilidad de extenderme en esa discusión, presentaré simplemente ambas versiones de la representación heróica de la poeta: en Guzmán a partir de la figura de "la Virgen demoníaca" y en Marchant a partir de "la Poeta del Árbol-Cristo". Luego, identificaré algunas figuras poéticas que propongo leer como performances marianistas paganas: Gaia, María Magdalena, la Antimalinche y la Sybila.

14 Sin posibilidad de transcribir aquí los poemas a los que haré alusión, invito a su lectura previa. 
Partiendo del análisis de una serie de poemas de Desolación, Ternura, Tala y Lagar cuyo carácter Guzmán considera unitario y fundamental, el autor desarrollará la idea de un heroísmo femenino en el marco de una tragedia heterosexual en la que los celos y el asco de la sexualidad conformarán el nudo conflictual: "un drama simbólico cuyos protagonistas centrales son un hombre y una mujer, pero en el cual el agente de todos los cambios, transformaciones y peripecias, es la mujer" (13). Me focalizaré brevemente en los que considero algunos de los análisis de Guzmán más atingentes a nuestro problema, que corresponden a "Poema del hijo", "Dios triste" (ambos en Desolación) y "La cabalgata" (en Tala).

A partir del poderoso verso "Bendito sea mi vientre en que mi raza muere!" de "Poema del hijo", Guzmán sostendrá que la poeta bendice su vientre en tanto sepultura. Invirtiendo el "Ave María", la "yo" ocupa la posición de virgen, salvo que esta vez es una suerte de virgen demoníaca ... [Se trata] de una femineidad violenta y resentida ... [que] decide dar la muerte en lugar de vida, para terminar con la condición miserable de la madre, es decir, de la mujer ... Pocos gestos poéticos de más colosal rebeldía contra el sentido mismo de la civilización cristiana ... Ella ... no pertenece al plan natural ... La renuncia a la maternidad, pues, le ha dado a ella carácter sacro, la ha colocado en posición de redentora de la raza humana ... La función de esa renuncia mítica a la maternidad real es la de producir poemas ... en vez de la producción de niños ... La masculinidad básica de estos poemas está muerta desde el principio, por acción de una mujer ... Ha sido esa misma mujer ... la que ha restituido el sentido a la realidad y también sus objetos, en un acto de creación propiamente divino (39-45, el énfasis es mío).

Esta "tragedia heterosexual" también sería identificable en el poema mistraliano al Dios "herido, olvidado y fatigado", de cuyas imágenes Guzmán asevera la referencia al "padre popular alcohólico"15

El padre no ocupa el lugar que la cultura judeo-greco-latina le dio como centro de la realidad, origen y mantenedor del orden y del sentido, y se ha convertido en una pura ausencia... El padre debería estar presente, todo lo requiere y lo postula... Su presencia plena permitiría a cada cosa ser lo que es en el seno de una jerarquía disponible: hombre a los varones, mujer a las hembras, patria a los países. En cambio... aquí los padres sangran y lloran, llevan y dejan... Justo al revés de lo que ocurre con la madre ... el padre es siempre un espejismo ... en nuestra realidad mestiza [él es] un fantasma referencial, expuesto y asumido en estos poemas (63-7, el énfasis es mío).

15 Al respecto, es importante consignar el sesgo de clase y género de las campañas higienistas anti-alcohol de los años 1920-1930 en Chile (Illanes 2007; Lavrín 1995). 
Finalmente, el poema "La cabalgata" le permitirá a Guzmán enunciar de manera concluyente el heroísmo de "la Poeta" mestiza:

Fue el hecho de haber vivido en un mundo donde los héroes, es decir, los padres, no existen, lo que le hizo cambiar [al yo mistraliano] el ansia de su carne por 'fábulas' ('relatos', 'palabras') ... El padre ausente es el centro vacío de estos poemas, como lo es de la vida de toda mujer latinoamericana ... El Padre ha sido sustituido por 'el Macho', por 'el Chingón', por 'el Compadrito', también por el Dictador, por 'el Rico', por 'el Latin Lover', todas figuras masculinas incapaces de darle un sentido que vaya más allá de la náusea a una realidad que al castrar a sus hombres, robándoles su destino, su identidad, su autorrespeto, su creatividad, condena a la femineidad al heroísmo poético (76-7, el énfasis es mío).

Considerando que la obra de Mistral efectivamente permite la interpretación heteronormada de Guzmán, propongo atender a las ansiedades del "hijo mestizo" aquí involucradas. Renegando de las figuras masculinas estereotipadamente incapaces, la interpretación de Guzmán parece abogar por devolverle a los hombres latinoamericanos la virilidad y el autorrespeto que la castradora "realidad mestiza" les habría sustraído, impidiéndoles ser verdaderos padres y verdaderos héroes. En ese imaginario en el que el amor (heterosexual) está condenado de antemano al fracaso, la responsabilidad de la re-virilización del padre recae en "sus mujeres". Frente a este escenario, "la femineidad latinoamericana de excepción” representada por Mistral, tomaría distancia de los cuerpos femeninos sexuados y burlados, al mismo tiempo que se condena al heroísmo poético. Guzmán subestima con ello, el hecho de que Mistral podría haber elegido ese heroísmo.

En esta misma línea de análisis, Marchant (2000b) afirma que es "el rencor del hijo" el que hace afirmar a Guzmán que "la mujer latinoamericana” no podría ser creadora más que a causa de una insatisfacción o derrota amorosa y sexual. El autor sostendrá también que Guzmán plantea de manera falsa y esencialista la cuestión del "padre fantasma" en tanto "exclusividad latinoamericana".

En Sobre árboles y madres, Marchant tomará muchos de los mismos poemas a los que hace referencia Guzmán afirmando, sin embargo, que es necesario desarrollar un análisis que no sólo considere el "contenido manifiesto" de la poesía mistraliana, sino que también su "contenido latente". Sin posibilidad de extenderme en la lectura desafiante de Marchant, creo importante hacer una breve alusión a lo que el autor denomina "la figura del Árbol-Cristo" en la obra de Mistral.

Marchant sostiene que para la poeta, el cristianismo oficial no sería más que una interpretación errónea de un conjunto de representaciones: "Cristo es madre (...) (la poetisa y la maestra de escuela deben, si se quiere entender rectamente el sacrificio de Cristo, consumar la acción redentora)” (El árbol 124, el énfasis es mío). Además, la poetización del Árbol-Cristo haría parte de una "escritura mestiza" ya que, según 
Marchant, "la gran teoría del mestizaje" de Mistral depende de una cuestión crucial: "más que la cuestión de la violación de la madre, el sentirse el latinoamericano, él, 'hijo violado'. Deseo de un padre como deseo de uno de ser 'uno mismo"' (Qué puede hacer un pobre hombre...?210). Y agrega: "el mestizaje, como tal, se realiza, se cumple como escritura” (211). Así, según Marchant, la poesía mistraliana hablará de la muerte de la Madre Arcaica y de la posibilidad de su "resurrección como escritura" (211). El autor concluye que es de la poetización del Árbol-Cristo que depende la posibilidad de resurrección y restauración "del reino de las madres" (Sobre árboles 161): he ahí el proyecto heroico y la utopía mistraliana.

A pesar de sus diferencias, tanto la "Virgen demoniaca" como la "Poeta del Árbol-Cristo" constituyen figuras heroicas representantes de un marianismo pagano que, en tensión con la performance marianista "La Maestra civilizadora", vehiculizan un malestar en relación a la sentencia "la biología es destino".

A partir de esta clave de lectura, propongo leer algunas figuras poéticas destacadas por los críticos Mario Rodríguez, Grínor Rojo, Patricio Marchant y Adriana Valdés: la Antimalinche, Gaia, María Magdalena y la Sybila.

Mario Rodríguez no dudará en designar al yo poético mistraliano como "la Anti-Malinche", aquella que se rebela frente al destino dramático reservado a "la mujer hispanoamericana", la "que no está dispuesta a ser 'chingada', ni 'rajada', ni penetrada... La sujeto mistraliana rechaza precisamente ese desorden del cuerpo, esa bestialidad tumultuosa que transforma los cuerpos (rostros y entrañas) en carne convulsa y pletórica" (133-7). Según el autor, este rechazo "la sitúa plenamente en la concepción judeo-cristiana del mundo que resalta el carácter mortífero del deseo" (137) y, simultáneamente, en la historia del medioevo español: “aquella época propuso una significación doble de la mujer, que nutre el fondo de las creencias latinoamericanas sobre el ser femenino: la virgen y la prostituta. Ambos arquetipos semantizan espacios de exclusión violenta" (137). La virginidad entonces, equivaldría a

\footnotetext{
oponerse a una violación histórica: la del conquistador, y a rechazar la violencia de su continuador, el padre, poniendo fin a la repetición incesante de un acto de violencia original, paradojalmente, mediante otro acto violento [...] La retención erótica $[\ldots]$ significa cerrarse al otro, violentar una relación plena con el mundo, pero también clausurar la propagación de una violencia originaria (139, el énfasis es mío).
}

Grínor Rojo, por su parte, identifica dos figuras paganas que se definen por oposición a la versión institucional de la Virgen María. En efecto, Rojo sostendrá que María no es en ningún caso uno de los personajes preferidos de Mistral en su poesía. Ella preferirá a las mujeres del Antiguo Testamento, pero por sobre todo a Gaia, la figura pagana que representa a la Madre Tierra y que comparte el panteón mistraliano con el Dios-Padre y el Dios-Hijo. Comentando los "Nocturnos" de Tala, Rojo sostendrá que la poeta opera una re-jerarquización entre el Yavhé israelita y la Gaia pagana y 
que será en su relación con el Dios-Hijo que aparece la posibilidad de reconciliación de la 'yo' mistraliana con el cristianismo.

Rojo también se detiene en un bello poema, "Nocturno del descendimiento", en el que María Magdalena hace aparición como figura simultáneamente polémica y prestigiosa, ya que es ella quien ostenta un lazo exclusivo con Cristo: es María Magdalena quien después de su muerte, lo reconoce antes que todos: "El, que a todos pertenece, ahí, en la noche del alma, sólo a ella responde” (Dirán 182).

Patricio Marchant coincide con Rojo al sostener que la poeta redentora no se identifica tanto con la Virgen María como con María Magdalena. En efecto, cantar "el carácter maternal de Cristo" (124-5) es una misión de la poeta que depende de un don, un saber, un secreto...encarnado en la figura de María Magdalena. Es ella la que impone la separación como un don, es ella la que sabe que el hijo necesita separase para devenir El Hombre. María sigue a Juan. En cambio, de María Magdalena no se sabe más: es ella quien se queda sola porque no acepta cambiar a su hijo por otro. En resumen, según Marchant, es gracias a María Magdalena que el cristianismo sería "el propietario de una buena madre", con la que Mistral se identifica (Sobre árboles 36).

Finalmente, sugiero pensar en una última auto-representación poética de esta misma familia, tematizada por Adriana Valdés. La autora se concentrará en Tala, cuestionando "la identidad indoamericana" como clave de lectura tradicional del libro y proponiendo en su lugar la imagen de "un campo de batalla" en el que una "sujeto mujer" - "que hasta en poesía pide permiso"- "dejó las huellas de su lucha por constituirse" (97). Se trataría de un sujeto "extranjero, culturalmente migratorio, ubicado en la intersección de culturas distintas y haciendo entre ellas sus movidas de supervivencia: un sujeto particularmente latinoamericano, no en su afirmación, en su despojo" (96-7).

Una de las protagonistas de estas batallas es, según la autora, la figura de la vieja sacerdotisa o la Sybila, su variante como profeta. Según Valdés, si en Desolación Mistral le habla al "Dios triste", en Tala la poeta dialoga con el Cristo en tanto "bulto vencido" (Mistral, "Nocturno" 324). Para hablar con Él, la poeta toma la máscara de la vieja sacerdotisa, "la que se construye desde la privación del sexo" (88):

alguien que hace gestos consagrados por el cristianismo. Pero es a la vez una transgresora: declara al Cristo muerto y se pone en el lugar de su madre; se hace, ella, mujer, sacerdote y administra un sacramento cristiano. Se toma en la palabra un poder que el esquema patriarcal le niega. El esquema patriarcal se agotó junto... con la juventud. Requisito del sacerdocio femenino es la vejez y la renuncia a la relación erótica: toda relación es enseñanza, y al imperativo de la atracción sexual se sustituye el imperativo de la sabiduría. Vejez, sabiduría, poder sacerdotal van juntos. Podría hablarse en Gabriela Mistral de una temprana nostalgia de vejez... Podríamos también hablar de la asunción temprana de la vejez como una especie de alivio respecto de las heridas del deseo erótico: un ponerse más allá de todo; un erigir voluntariosamente otro poder, frente al poder del 'amo amor' que regía Desolación (89, el énfasis es mío). 
Y como adivinando los efectos de las performances marianistas entre las mujeres latinoamericanas:

Reflexión para amigas feministas (yo entre ellas). Asumir el poder sacerdotal, en Tala, es seguir con el proceso de 'cortar el gozo a cercén'. Es aprender un amor que es terrible [...] La mujer que habla asume la máscara de la vieja, la identidad de la vieja, en una especie de huida hacia adelante que le permite escapar de ese agente de sujeción que es su propio deseo, la posibilidad de desear. El ascetismo, entonces, como condición del indefenso; lo que le permite no estar a merced del deseo (95, el énfasis es mío).

\section{Existir para el Estado-nación: paradojas de la performance marianista}

Tal como hemos sostenido y siguiendo a Varikas $(2006,2007)$, la idea moderna de nación es constitutiva de las identidades sexuales: la función simbólica de la diferencia sexual en la retórica de "la pureza nacional" es la de localizar a "los otros". En ese imaginario heteronormado, los cuerpos de las mujeres han representado el territorio o el cuerpo nacional: allí, el fantasma de la violación señala el terror a ser colonizado, invadido por "los otros" (las otras naciones).

A comienzos del siglo XX, en un escenario nacionalista conflictivo marcado por "la cuestión social" y el complejo de inferioridad frente al "progreso" de Europa y Estados Unidos, Lucila acude a una performance marianista que tranquiliza las ansiedades y reviriliza a los Estados latinoamericanos: son ellos, y no el imperialismo "blanco", los que tendrán el derecho a definir la presentación del cuerpo excepcional de Mistral.

En efecto, si como hemos sostenido, en la figura puericultural de "la madre popular" se concentraron las ansiedades del nacionalismo en la época en la que Mistral vivió, y si esas ansiedades reeditaron la representación del cuerpo femenino abierto y responsable de la derrota frente al "blanco", es demostrando su "excepción" en relación a "las malas mujeres de la nación” que Mistral urdirá una presentación de sí misma que amerita la aprobación y el maridaje con el Estado-nación posibilitando, simultáneamente, oportunidades heterogéneas y muchas veces contradictorias, de asimilación, resistencia y reconocimiento para la poeta.

La performance marianista mistraliana consistirá, entonces, en un conjunto de auto-representaciones mesiánicas de la femineidad desplegadas en el espacio público y/o escritural que se esforzaron por sostener la maternidad asexuada como patrimonio, límite de la dignidad nacional, inaccesibilidad estoica en pos de la protección de un hijo-nación.

La noción performace nos permitió analizar estas autorepresentaciones no como algo "falso" que oculta una "autenticidad", sino como una serie de contradicciones encarnadas y vividas en un contexto histórico y discursivo específico; una estrategia no unilateral, 
ni totalmente autoconsciente o soberana de sí misma; una creación discursiva errática y dinámica, que involucró diversos actores, condiciones de producción y de recepción (la crítica literaria, los discursos puericulturales, el relato marianista, los nacionalismos latinoamericanos y a la propia Lucila). Es desde esa clave de lectura que hemos intentado "superar la dicotomía sumisión/revuelta" (Varikas, L’approche 53) a través de la cual tendemos a interpretar la vida y obra de ésta y otras "mujeres de excepción".

Respondiendo a la demanda de revirilización de los Estados "mestizos" ofendidos por los Estados "blancos", Mistral participará de la creación paradojal de su propia alegoría. La "Maestra de Latinoamérica" y "la Poeta Redentora" se proponen entonces como performances de "la madre espiritual la nación" que reinstalan "el sentido maternal de las cosas" en el mundo. En este sentido, ambas performances marianistas proponen la inversión como estrategia (Varikas, Les Rebuts) y no necesariamente la ruptura con los términos binarios planteados por el relato latinoamericanista.

Sin embargo, en esa lucha individual por el reconocimiento, Mistral deja ciertas huellas de inconformidad y desacuerdo con su propia performance que develan las contradicciones inherentes al problema político en el que se enmarca la estrategia del excepcionalismo.

En efecto, la misma presentación corporal que es indispensable para performear a "la Maestra de Latinoamérica" y a "la Poeta Redentora" (inaccesible, incorruptible, etérea, más allá de la sexualidad), la acercan peligrosamente de la ambivalencia sexual. De esta manera, la femineidad del ícono Mistral resulta paradójica: ni demasiado masculina ni demasiado femenina, siempre en proceso. Cuestión que como hemos analizado, constituye parte de su excepcionalidad.

Por otra parte, es posible constatar que las performances de "la Maestra de América Latina" y de la "Poeta redentora" son portadoras de misiones distintas. Si ambas implican una cierta presentación corporal y espiritual, la excepcionalidad sexual, racial y de género de "la Maestra", trabajarán en dirección de la misión civilizadora encomendada por el Estado. En cambio, la excepcionalidad pagana de "la Poeta" y sus figuras (vírgenes demoniacas, diosas de la tierra, sacerdotisas salvajes, marías magdalenas que saben lo que otros ignoran) solidarizarán con "las madres de la raza", pregonando en su poetizar, la injusticia del "patriotismo biológico" y la utopía de otro destino para las mujeres latinoamericanas.

Finalmente, aunque "la Maestra de América Latina" y "la Poeta redentora" constituyeron intentos de reivindicación la dignidad de "la mujer latinoamericana" mancillada en el imaginario nacional, la performance marianista continúa reiterando los términos género-racializados definidos por ese imaginario. Así, en la medida en que el empoderamiento de estas figuras depende de la negación o sublimación del sexo, la performance marianista confirma la metonimia entre sexualidad femenina, territorio expuesto y traición y, con ello, la jerarquía entre "las ilustradas" y "las ignorantes", "las blancas" y "las morenas", "las femeninas" y "las sospechosas", "las morales" y "las inmorales", "las buenas" y "las malas" mujeres de la nación. 


\section{Referencias}

Althaus-Reid, Marcella. La teología indecente. Barcelona: Ediciones Bellaterra, (2005). Medio impreso.

Achin, Catherine y Dorlin, Elsa. “J’ai changé, toi non plus. La fabrique d’un-e Présidentiable : Sarkozy/Royal au prisme du genre”. Mouvements, 2007. Fecha de ingreso: 3 de mayo de 2007. <http://www.mouvements.info>. Sitio web.

Ardao, Arturo. Nuestra América Latina. Montevideo: Ediciones de la Banda Oriental, 1990. Medio impreso.

Arendt, Hannah. La tradition cachée. Le juif comme paria. Paris: Christian Bourgois Editeur, 1987. Medio impreso.

---. Rahel Varnhagen. Vida de una mujer judía. Barcelona: Lumen, 2000. Medio impreso.

Baudot, Georges "Malintzin, l'irrégulière”. Femmes des Amériques. Actes du Colloque international Toulouse, 18-19 avril 1985. Ed. Claire Pailler. Toulouse: Publications Université de Toulouse-Le Mirail, 1986. 19-29. Medio impreso.

Bhabha, Homi. Les lieux de la culture. Une théorie postcoloniale. Paris : Payot, 2007. Medio impreso.

Boidin, Capucine. "Métissages et genre Dans les Amériques: des réflexions focalisées sur la sexualité". CLIO, Histoire, femmes et sociétés 27 (2008). Fecha de ingreso: 4 de enero de 2011. <http://clio.revues.org.index7492.html>. Sitio web.

Butler, Judith. El género en disputa. El feminismo y la subversión de la identidad. Barcelona: Paidós, 2007. Medio impreso.

Castro-Gómez, Santiago. Crítica de la razón latinoamericana. Barcelona : Puvill Libros, 1996. Medio impreso.

Dorlin, Elsa. "De l'usage épistémologique et politique des catégories "sexe" et de "race" dans les études sur le genre". Cahiers du Genre 2/39 (2005): 83-105. Medio impreso.

---. "Performe ton genre, performe ta race!: Re-penser l'articulation entre sexisme et racisme à l’ère de la postcolonie". Les soirées de Sophia (2007). Fecha de ingreso: 7 de noviembre de 2009. <http://www.sophia.be/app/webroot/files/2006-2007\%20 -\%20_Performe\%20ton\%20genre,\%20performe\%20ta\%20race_\%20-\%20 Elsa\%20Dorlin.pdf>. Sitio web.

Dulong, Delphine y Matonti, Frédérique. "L’indépassable 'féminité. La mise en récit des femmes en campagne”. Mobilisations Électorales. Le cas des élections municipales de 2001. Eds. Jacques Lagroye, Patrick Lehingue y Frédéric Sawicki. Paris : PUF, 2005. 281-303. Medio impreso.

Fanon, Frantz. Peau noire, maques blancs. Paris : Editions du Seuil, 1952. Medio impreso. Fiol-Matta, Licia. “The 'Schoolteacher of America': Gender, Sexuality, and Nation in Gabriela Mistral”. ¿Entiendes? Queer Readings, Hispanic Writings. Ed. Emilie Bergmann, Paul Smith. Durham: Duke University Press, 1995. 201-229. Medio impreso. 
---. A queer mother for the nation. The State and Gabriela Mistral. Mineapolis: University of Minessota Press, 2002. Medio impreso.

Franco, Jean. Plotting Women. Gender and Representation in Mexico. New York: Columbia University Press, 1989. Medio impreso.

Freedman, Jane. Femmes Politiques: Mythes et Symboles. Paris : L'Harmattan, 1997. Medio impreso.

García de la Huerta, Marcos. Reflexiones americanas: ensayos de intra-historia. Santiago: LOM, 1999. Medio impreso.

Graham, Richard. The idea of Race in Latin America 1870-1940. Austin: University of Texas Press, 1990. Medio impreso.

Gullberg, Hjalmar. "Award Ceremony Speech”. Fecha de ingreso: 11 de diciembre de 2011. <http://www.nobelprize.org/nobel_prizes/literature/laureates/1945/ press.html $>$. Sitio web.

Guzmán, Jorge. Diferencias Latinoamericanas. Santiago: Centro de estudios Humanísticos de la Facultad de Ciencias Físicas y Matemáticas, Universidad de Chile, 1984. Medio impreso.

Hedrick, Tace. Mestizo Modernism. Race, Nation, and Identity in Latin American Culture (1900-1940). Londres: Rutgers University Press, 2000. Medio impreso.

Hobsbawm, Eric y Terence Ranger. La invención de la tradición. Barcelona: Crítica, 2002. Medio impreso.

Horan Elizabeth. "Sor Juana and Gabriela Mistral: Locations and Locutions of the Saintly Woman”. Chasqui 25/2 (1996): 89-103. Medio impreso.

---. "Santa Maestra Muerta: Body \& Nation in Portraits of Gabriela Mistral”. Taller de Letras 25 (1997): 21-43. Medio impreso.

Illanes, María Angélica. Cuerpo y sangre de la política. La construcción histórica de las visitadoras sociales (1887-1940). Santiago: LOM, 2007. Medio impreso.

Laqueur, Thomas. La Fabrique du Sexe. Paris: Gallimard, 1992. Medio impreso.

Lavrín, Asunción. Women, Feminism and Social Change in Argentina, Chile and Uruguay: 1890-1940. Lincoln: University of Nebraska Press, 1995. Medio impreso.

Leys Stepan, Nancy. The Hour of Eugenics. Race, Gender, and Nation in Latin America. New York: Cornell University Press, 1991. Medio impreso.

Ludmer, Josefina. “Tretas del débil”. La sartén por el mango. Encuentro de escritoras latinoamericanas. Eds. Patricia González, Eliana Ortega. Río Piedras: El Huracán, 1985.47-54. Medio impreso.

Marchant, Patricio. Sobre árboles y madres. Santiago: Gato Murr, 1984. Medio impreso.

---. "El árbol como madre arcaica en la poesía de Gabriela Mistral (1982)”. Escritura y Temblor. Eds. Pablo Oyarzun, Willy Thayer. Santiago: Cuarto Propio, 2000a. 111-26. Medio impreso.

---. “Qué puede hacer un pobre hombre frente a una mujer genial? (1988)”. Escritura y Temblor. Eds. Pablo Oyarzun, Willy Thayer. Santiago: Cuarto Propio, 2000 b. 199-212. Medio impreso. 
Mistral, Gabriela. "Algo sobre higiene social en la América hispana”. Revista de las Españas 2 (agosto 1926). Fecha de ingreso: 13 de noviembre de 2013. <http:// www.filosofia.org/hem/dep/rde/re002122.htm>. Sitio web.

---. Lecturas para Mujeres. Ciudad de México: Porrúa, 1988. Medio impreso.

---. "Canciones de cuna y rondas ". Gabriela Mistral para niños. Ed. Aurora Díaz. Madrid: Ediciones de la Torre, 1994. 117-122. Medio impreso.

---. “Nocturno del descendimiento". Poesías completas. Comp. Jaime Quezada. Santiago: Andrés Bello, 2001. 324-325.Medio impreso.

Monsiváis, Carlos "La Malinche y el malinchismo". La Malinche, sus padres y sus hijos. Ed. Margo Glantz. México: Taurus, 2001. 183-93. Medio impreso.

Montecino, Sonia. Madres y huachos: alegorías del mestizaje chileno. Santiago: Catalonia, 2007. Medio impreso.

Oyarzún, Kemy. "Genealogía de un ícono: crítica de la recepción de Gabriela Mistral". Nomadías 3 (1998). Fecha de ingreso: 4 de junio de 2009. <http://www.gabrielamistral.uchile.cl/estudios/nomadias/koyarzun.html>. Sitio web.

Paz, Octavio. El laberinto de la soledad. México: Fondo de Cultura Económica, 1950. Medio impreso.

Pizarro Ana. "Gabriela Mistral en el discurso cultural”. Una palabra cómplice. Encuentro con Gabriela Mistral. Ed. Raquel Olea y Soledad Fariña. Santiago: Cuarto Propio, 1990. 99-107. Medio impreso.

Riot-Sarcey, Michèle y Varikas Eleni. “Réflexions sur la notion d'exceptionnalité”. Les Cahiers du GRIF 37-38 (1988): 77-89. Medio impreso.

--- "Feminist consciousness in the nineteenth century: a pariah consciousness ?". Praxis International 5/4 (1986): 443-65. Medio impreso.

Rivière, Joan "La femineidad como máscara”. Trad. Adriana Velásquez y María Ponce León. Athenea Digital 11 (primavera 2007): 219-26. Fecha de ingreso: 5 de septiembre 2013. <http://www dialnet.unirioja.es/descarga/articulo/2289584. pdf $>$. Sitio web.

Rodríguez, Mario, “Gabriela Mistral: la Antimalinche ». Atenea 459-460 (1989): 131 9. Medio impreso.

Rojo, Grínor. Dirán que está en la gloria...(Mistral). Santiago: Fondo de Cultura Económica, 1997. Medio impreso.

---. “Summa mistraliana”. Nomadías 3 (1998) N³. Fecha de ingreso: 4 de junio de 2009. http://www.gabrielamistral.uchile.cl/estudiosframe.html. Sitio web.

Rubio, Patricia. "Sobre el indigenismo y el mestizaje en la prosa de Gabriela Mistral". Taller de Letras número especial (1996): 25-40. Medio impreso.

Subercaseaux, Bernardo. Historia de las ideas y de la cultura en Chile. Tomo IV: $\mathrm{Na}$ cionalismo y cultura. Santiago: Universitaria, 2007. Medio impreso.

Valdés, Adriana. "Identidades tránsfugas (Lectura de Tala)". Una palabra cómplice. Encuentro con Gabriela Mistral. Ed. Raquel Olea y Soledad Fariña. Santiago: Cuarto Propio, 1990. 85-97. Medio impreso. 
Vargas Saavedra, Luis. Vuestra Gabriela: Cartas inéditas de Gabriela Mistral a los Errázuriz Echeñique y Tomic Errázuriz. Santiago: Zig-Zag, 1995. Medio impreso. Varikas, Eleni. Penser le sexe et le genre. Paris: PUF, 2006. Medio impreso.

---. Les rebuts du monde. Paris: Stock, 2007. Medio impreso.

Vasconcelos, José. La Raza cósmica. Misión de la raza iberoamericana. México: Libreros Mexicanos Unidos, 1958. Medio impreso.

Vera, Antonieta. “La supériorité morale des femmes' au Chili : un discours civilisateur" Tesis Doctoral. Université Paris VIII, 2012. Medio impreso.

Zermeño-Padilla, Guillermo, "Del mestizo al mestizaje: arqueología de un concepto". Revista Memoria y Sociedad 12/24 (2008): 79-95. Medio impreso.

Recibido: 03 diciembre 2013 Aceptado: 02 mayo 2014 